\title{
Translitteraturhistorien i belysning
}

Holmqvist, Sam Transformationer: I80o-talets svenska translitteratur genom Lasse-Maja, C. J. L. Almqvist och Aurora Ljungstedt (diss.). Stockholm: Makadam 2017 (334 sidor)

SAM HOLMQVISTS AVHANDLING i litteraturvetenskap analyserar litterära transmotiv från I80o-talets Sverige. Den vänder sig uttalat till en läsekrets både inom och utom akademin, vilket är utmärkt och borde ske mycket oftare i synnerhet inom den humanistiska forskningen som ju faktiskt har ett allmänintresse. Transformationer: I80o-talets svenska translitteratur genom Lasse-Maja, C. J. L. Almqvist och Aurora Ljungstedt (20I7) har i denna mening ett genomarbetat upplägg och en kongenial layout där de mer inomakademiska delarna - teoretisk inledning och noter - är gråfärgade och därmed lätta att hitta (eller hoppa över!). Därtill finns utbrutna faktarutor som kan läsas om intresse finnes. Dessutom lyfter Holmqvist fram frågan om vad skönlitteratur faktiskt kan betyda för personer med levda transerfarenheter, alltså om fiktionens betydelse i verkligheten. Den frågan är naturligtvis alldeles för svår att besvara, både utifrån avhandlingens val av historiskt undersökningsmaterial och i teoretisk-filosofisk mening, men tanken är god.

Genom studier av framför allt tre verk från i80o-talet diskuterar Holmqvist litterära transpersoner avant la lettre och på köpet får läsaren också inblick i dagens teoretiska perspektiv på begreppet "trans”. Holmqvist väljer att uppfatta begreppet som en process, beskriven med 
verbet "transgörande", vilket jag tror är en bra utgångspunkt. Ett begrepp i rörelse undviker essentialistisk fastlåsning och öppnar för möjligheten att betrakta identitet som något flytande snarare än som en fast entitet, något som kan te sig olika i skilda tider och på andra platser.

Med fokus på könsöverskridande som litterärt motiv analyserar Holmqvist Lars Molins självbiografi Den riksbekante Lasse-Majas besynnerliga öden (1833), Carl Jonas Love Almqvists historiska roman Drottningens juvelsmycke (1834) och Aurora Ljungstedts spänningsroman Moderna typer (1872).

Det vanligaste transnarrativet från I 80o-talet kan förenklat beskrivas som att en lite mystisk och hemlighetsfull romangestalt avslöjas, eller avslöjar sig själv, efter att ha framställt sig själv som ett annat kön än det som tillskrivits vid födseln. Ordningen återställs genom att romangestalten återgår till sitt tilldelade kön. Därmed förutsätts kroppen vara bärare av "sanningen" och det finns således i dessa texter en föreställning om att det går att finna och fastslå "det verkliga könet". Denna uppfattning skiljer sig förstås från dagens transteorier, men just därför blir den intressant att undersöka med hjälp av den här typen av nutida tankegångar eftersom synen på kön i I8oo-talets Sverige då avnaturaliseras, främmandegörs och blir tillgänglig för granskning och analys.

Lasse-Maja, "stortjuven i kvinnokläder", var en riktig kändis på sin tid. Myten om Lasse-Maja befästes i Lars Molins bästsäljande självbiografi och den lever kvar i diverse filmatiseringar och tv-serier. I myten är han en skojfrisk och folkkär bov som tog från de rika och gav till de fattiga. När han väl fängslades och hamnade på Karlstens fästning blev han en sevärdhet som till och med kronprinsparet besökte. Det speciella med Lasse-Maja var könsväxlingarna. Efter att ha levt sina första sjutton år som Lars Molin lånade han prästbetyg, kläder och namn av sin dåvarande flickvän och därefter levde hen växelvis som man och kvinna under resten av livet. I denna mening blir Lasse-Maja en skälmgestalt som överskrider inte bara könsgränser, utan även andra sociala ordningar. Men genom att inta rollen av den roliga anti-hjälten blir Lasse-Majas könsväxlingar avvikelser som tillfälligt utmanar utan att i grunden förändra normernas status quo. 
Lazuli Tintomara i Almqvists klassiker Drottningens juvelsmycke är en gåtfull gestalt som forskningen ägnat mycken möda åt att försöka förklara i termer av antingen animal coeleste, ett himmelskt väsen, hermafrodit eller ung flicka. Det är därför beundransvärt att avhandlingen lyckas ge nya perspektiv på denna genomtröskade roman! Holmqvist vågar nämligen stanna kvar $\mathrm{i}$ gåtan och ambivalensen och menar att Lazuli Tintomara å ena sidan utgör en patriarkal fantasi om den lockande, kvinnliga androgynen, men å andra sidan utgör en möjlig identifikationspunkt för transpersoner, i synnerhet i de ögonblick då Lazuli Tintomara uppvisar uppenbar obekvämlighet i påtvingade könsuttryck.

I romanen Moderna typer kritiserar Aurora Ljungstedt modernitetens uttryck, vilka ses som ytligt och opålitligt inautentiska till skillnad från fasta och trygga "autentiska" värden. I nationalismens namn blir de främmande lurendrejare som "klär ut sig" till ett annat kön än det de tilldelats, till annan klasstillhörighet eller etnicitet, motsatsen till den stabila identitet som i denna roman i positiv mening betecknas som svensk. När en ciskvinna av pragmatiska skäl klär sig som man, men så snart det är möjligt slutar med det, framstår detta som något begripligt och rentav rekommendabelt. Transkvinnan däremot, som går nedåt $\mathrm{i}$ den sociala ordningen, utgör snarare något farligt att skrämmas av eller något löjligt groteskt att skratta åt.

Avslutningsvis pekar Holmqvist fram mot I900-talet och läser då bland annat Amanda Kerfstedts roman Reflexer (I90I, finns i nyutgåva av Rosenlarv förlag 2010 med efterord av Maria Andersson) och Frida Stéenhoffs novell "Ett sällsamt öde" (I9II), vilka skänker tydlig relief till avhandlingens huvudsakliga undersökning av ı80o-talets litteratur. Runt I90o "uppfinns" nämligen transpersonen av den sexologiska vetenskapen och därför framstår seklet som precis föregått kategoriseringen som extra viktigt och intressant. Sammantaget har I80o-talslitteraturen gestaltat könsöverskridandets motiv på både positiva och negativa sätt, som något tillfälligt avvikande och sällsynt eller som motbild, men Holmqvists viktiga poäng är att i båda fallen cementeras könsbinariteten i slutändan. Undersökningar av transmotivet implicerar därför alltid en analys av könsnormer. 
Det som ändå saknas i Holmqvists ambitiösa pionjärstudie är den tidiga feministiska forskningen i Sverige. Frågan om translitteratur vrids och vänds och även frågan om historia och historisering diskuteras i avhandlingen. Men vad innebär egentligen litteraturbistoria? Den aspekten berörs inte och därigenom osynliggörs den tidigare feministiska forskning som bland annat initierat en problematisering av litteraturhistorieskrivningen. Någon not till föregångarna hade varit strategiskt snyggt, i synnerhet som dessas uppfattning om litteraturläsningens emancipatoriska potential torde ha utgjort en källa till rörande enighet med avhandlingsförfattaren.

Men framför allt utgör Transformationer sammanfattningsvis en både vacker och viktig bok som lägger de första byggstenarna till en svensk translitteraturhistoria. Undersökningen av könsöverskridandet som litterärt motiv visar att detta kan bilda vidare teman, som i relation till de tre romaner som analyseras benämns "avvikelse", "gåta" och "nationalism". Visserligen fungerar dessa teman ibland normativt könsstabiliserande - men kan i slutändan ändå ha en subversiv verkan. 